\title{
Hydrogen sulfide regulates photosynthesis of tall fescue under low-light stress
}

\author{
Y.H. LIU", X.H. ZHANG ${ }^{\#}$, B.W. LIU, B. AO, Q. LIU, S.Y. WEN, and Y.F. XU' \\ College of Grassland Agriculture, Northwest A\&F University, 712100 Yangling, Shaanxi Province, China
}

\begin{abstract}
Hydrogen sulfide $\left(\mathrm{H}_{2} \mathrm{~S}\right)$ is regarded as gaseous signaling molecule in plant response to various biotic and abiotic stresses. In this study, we investigated potential role of $\mathrm{H}_{2} \mathrm{~S}$ in modulating photosynthesis in low light (LL) stress-induced tall fescue (Festuca arundinacea Schreb.) seedlings. Results demonstrated that LL significantly reduced the plant height, leaf width, tiller number, dry mass, turf quality, chlorophyll content, net photosynthetic rate, stomatal conductance, intercellular $\mathrm{CO}_{2}$ concentration, transpiration rate, maximal quantum yield of PSII photochemistry, photochemical efficiency of PSII, photochemical quenching, electron transport rate, and enzymatic activity of ribulose-1,5-bisphosphate carboxylase. Then, these parameters were found to be considerably alleviated by $\mathrm{H}_{2} \mathrm{~S}$ donor application. Moreover, exogenous application of NaHS decreased the concentration of malondialdehyde, increased activities of peroxidase, superoxide dismutase, ascorbate peroxidase, total soluble sugar, soluble protein, and endogenous concentration of $\mathrm{H}_{2} \mathrm{~S}$. In addition, these responses could be reversed by treatment with hypotaurine $\left(\mathrm{H}_{2} \mathrm{~S}\right.$ scavenger) and aminooxy acetic acid $\left(\mathrm{H}_{2} \mathrm{~S}\right.$ biosynthesis inhibitor). These results suggested that $\mathrm{H}_{2} \mathrm{~S}$ was possibly involved in the regulation of photosynthesis to strengthen LL tolerance by maintaining a high level of photochemical efficiency and improving antioxidant enzyme activities in tall fescue.
\end{abstract}

Additional key words: ascorbate peroxidase; carotenoids; gas exchange; lipid peroxidation; superoxide dismutase.

\section{Introduction}

Light is an essential resource for photoautotrophic higher plants including turfgrass for survival, growth, site distribution, and development (Huang et al. 2011). In a natural environment, plants are often subjected to erratic variations with time due to light intensities and fluctuations regulated by sun, angle of clouds, and leaf movement (Hirth et al. 2013). Currently, it has been accepted that shade is one of the most common environmental limiting factors for aesthetic value and service life of turf. It is evaluated that as much as $25 \%$ of turfgrass in America (Emmons 2008) and approximately $50 \%$ of that in China (Yang et al. 2014) is subjected to varying degrees of shade.

During developmental changes at whole-plant or leaf level, LL stress was found to have an impact on morphological parameters, physiological characteristics, and photosynthetic efficiency of plants (Li et al. 2017). Previous studies have reported morphological changes of plants in response to LL stress, such as thinner leaves (Fu et al. 2014) and lower biomass (Gustafsson and Boström 2013). Another study reported that LL could decrease the biosynthesis of photosynthetic pigments (Zhang et al. 2018) and reduce the chlorophyll $(\mathrm{Chl})$ fluorescence parameters (Chen et al. 2016). Under LL stress conditions, enzymes components of Calvin-Benson cycle, particularly Rubisco, exhibited an apparent tendency of diminishing activities leading to lower $\mathrm{CO}_{2}$ assimilation rate, eventually resulting in prominent depression of plant growth (Yang et al. 2018). Furthermore, LL irradiance contributed to the overproduction of ROS by increasing the electron flow to $\mathrm{O}_{2}$ during photosynthetic and respiratory processes, which resulted in membrane lipid peroxidation and protein denaturation ( $\mathrm{Li}$ et al. 2017). To alleviate the negative effect of excessive ROS, antioxidant enzyme activities were enhanced in plants to deal with different oxidative stresses (Candan and Tarhan 2003).

$\mathrm{H}_{2} \mathrm{~S}$ is an endogenous messenger molecule, which

\footnotetext{
Received 24 December 2018, accepted 6 May 2019.

${ }^{+}$Corresponding author; e-mail: xuyuefei@nwsuaf.edu.cn

Abbreviations: AOA - aminooxy acetic acid; APX - ascorbate peroxidase; Car - carotenoids; Chl - chlorophyll; $C_{\mathrm{i}}-$ intercellular $\mathrm{CO}_{2}$ concentration; $E$ - transpiration rate; EDTA - ethylene diamine tetraacetic acid; ETR - electron transport rate; $\mathrm{F}_{0}-$ minimal fluorescence yield of the dark-adapted state; $F_{m}$ - maximal fluorescence yield of the dark-adapted state; $F_{m}{ }^{\prime}-$ maximal fluorescence yield of the light-adapted state; $F_{s}$ - steady-state fluorescence yield; $F_{v} / F_{m}-$ maximal quantum yield of PSII photochemistry; $g_{\mathrm{s}}$ - stomatal conductance; $\mathrm{H}_{2} \mathrm{~S}$ - hydrogen sulfide; HT - hypotaurine; LL - low light; MDA - malondialdehyde; $P_{\mathrm{N}}$ - net photosynthetic rate; POD - peroxidase; $\mathrm{q}_{\mathrm{P}}$ - photochemical quenching coefficient; ROS - reactive oxygen species; RuBP - ribulose-1,5-bisphosphate; SOD - superoxide dismutase; $\Phi_{\mathrm{PSII}}$ - effective quantum yield of PSII photochemistry.

Acknowledgements: This work was supported by the Fundamental Research Funds for the Central Universities, National Undergraduate Training Program for Innovation and Entrepreneurship (No. 201810712010), and National Key R\&D Program of China (No. 2017YFE0111000). We appreciate three anonymous reviewers for useful suggestions about the manuscript.

\#These authors contributed equally to this work.
} 
modulates various important physiological processes in plants (Zhang et al. 2008). Numerous studies have reported the effects of $\mathrm{H}_{2} \mathrm{~S}$ in plants. $\mathrm{H}_{2} \mathrm{~S}$ not only promoted root organogenesis (Zhang et al. 2009) and seed germination (Li et al. 2012) but also delayed senescence ( $\mathrm{Hu}$ et al. 2015 ) in plants. Besides its function on growth regulation, $\mathrm{H}_{2} \mathrm{~S}$ also acts as a protective agent against multiple abiotic stresses induced by drought (Jin et al. 2013), heat (Li et al. 2012), salt (Wang et al. 2012), and heavy metals (Ali et al. 2014). In addition, $\mathrm{H}_{2} \mathrm{~S}$ could improve the photosynthesis in Spinacia oleracea seedlings through increased chloroplast biogenesis, photosynthetic enzyme expression, and thiol redox modification (Chen et al. 2011). In another study, $\mathrm{H}_{2} \mathrm{~S}$ was found to improve the photosynthesis in Dendrobium officinale under high light through the stimulation of antioxidant enzyme activities (Fan et al. 2014). However, the underlying mechanism of $\mathrm{H}_{2} \mathrm{~S}$ regulation of photosynthesis in tall fescue leaves induced by LL stress has not yet been illustrated.

Tall fescue (Festuca arundinacea Schreb.), a widespread perennial cold season forage or turfgrass, is known to survive various environmental stresses. It is usually cultivated under fluctuating light density regimes due to the detrimental effects of vegetation canopies, bushes, buildings or different weather patterns (Xu et al. 2013). In our previous study, it was reported that tall fescue suffered adverse effects on antioxidant defense system at different growth stages under LL stress, which were alleviated by application of sodium nitroprusside (nitric oxide donor) (Fu et al. 2014). However, little information is available with regards to $\mathrm{H}_{2} \mathrm{~S}$ mediated plant photosynthesis under LL stress, though previous study has shown that LL stress could cause diminution of photosynthetic characteristics (Zhong et al. 2014). In the present study, we hypothesized that $\mathrm{H}_{2} \mathrm{~S}$ is involved in photosynthesis of LL stress-induced tall fescue by maintaining a high photosynthetic rate and regulating antioxidant system. Therefore, the purpose of this study was to explore the role of $\mathrm{H}_{2} \mathrm{~S}$ in modulating carboxylation efficiency, Chl content, and PSII activity for better tolerance of tall fescue plants in LL stress conditions. This study could help us further understand the role of $\mathrm{H}_{2} \mathrm{~S}$ in improving LL tolerance of tall fescue.

\section{Materials and methods}

Plant materials and growth conditions: Tall fescue (Festuca arundinacea Schreb. cv. Arid3) seeds were obtained from Beijing Clover Seed \& Turf Co., China. The seeds were surface sterilized using $0.1 \%(\mathrm{w} / \mathrm{v})$ sodium hypochlorite, rinsed several times with distilled water, and subjected to germination on moistened filter paper at room temperature for $7 \mathrm{~d}$. After 7-d period, three healthy and morphologically uniform sized seedlings were selected and transferred into black plastic pots $(9-\mathrm{cm}$ diameter $\times 15-\mathrm{cm}$ depth) containing sterile quartz sand autoclaved at $180^{\circ} \mathrm{C}$ for $60 \mathrm{~min}$. Seedlings were watered every day and fertilized once every $3 \mathrm{~d}$ with Hoagland's nutrient solution containing $4 \mathrm{mM} \mathrm{Ca}\left(\mathrm{NO}_{3}\right)_{2}, 4 \mathrm{mM} \mathrm{KNO}{ }_{3}, 2 \mathrm{mM} \mathrm{MgSO}_{4}, 1 \mathrm{mM}$ $\mathrm{NH}_{4} \mathrm{H}_{2} \mathrm{PO}_{4}, 46 \mu \mathrm{M} \mathrm{H}_{3} \mathrm{BO}_{3}, 10 \mu \mathrm{M} \mathrm{MnSO}_{4}, 1.0 \mu \mathrm{M} \mathrm{ZnSO}_{4}$, $0.95 \mu \mathrm{M} \mathrm{CuSO}_{4}, 0.05 \mu \mathrm{M} \mathrm{H}_{2} \mathrm{MoO}_{4}$, and $50 \mu \mathrm{M}$ Fe-EDTA.
The nutrient solution $\mathrm{pH}$ was adjusted approximately to 6.5 using $\mathrm{H}_{2} \mathrm{SO}_{4}$ or $\mathrm{KOH}$. The plants were grown in a plant incubator at a day/night temperature of $25 / 20^{\circ} \mathrm{C}$, relative humidity of $60 / 50 \%, 16-\mathrm{h}$ photoperiod, and PPFD of $200 \mu \mathrm{mol} \mathrm{m}{ }^{-2} \mathrm{~s}^{-1}$ placed at plant height. Irradiance system was provided by $20000 \mathrm{~K}-20 \mathrm{~B}$ fluorescent lamps (Nanjing Huaqiang Electronics Co., Ltd., China) and appropriately spaced for uniform light intensity.

Treatment and experimental design: Stress treatments were carried out after $28 \mathrm{~d}$ of preculture. PPFD used for control and low light stress groups were at 200 and $40 \mu \mathrm{mol} \mathrm{m} \mathrm{m}^{-2} \mathrm{~s}^{-1}$, respectively. To apply exogenous $\mathrm{H}_{2} \mathrm{~S}$ to tall fescue seedlings, $\mathrm{NaHS}($ Sigma $)$ was used as $\mathrm{H}_{2} \mathrm{~S}$ donor (Fan et al. 2014). For further treatment, seedlings were divided into two groups. In the first group, seedlings were supplied with different concentrations of NaHS (100, 300, $500 ; 1,000$; and $1,500 \mu \mathrm{M})$ for $7 \mathrm{~d}$ to determine optimal concentration. In the second group, 28-d-old plants were separated into five groups exposed to different treatments for $7 \mathrm{~d}$ :

\begin{tabular}{ll}
\hline Treatment & \\
\hline distilled water & control, CK \\
distilled water under low light & $\mathrm{LL}$ \\
$500 \mu \mathrm{M}$ NaHS under low light & $\mathrm{LL}+\mathrm{H}_{2} \mathrm{~S}$ \\
$300 \mu \mathrm{M} \mathrm{HT}\left(\mathrm{H}_{2} \mathrm{~S}\right.$ scavenger) under low light & $\mathrm{LL}+\mathrm{HT}$ \\
$300 \mu \mathrm{M}$ AOA $\left(\mathrm{H}_{2} \mathrm{~S}\right.$ biosynthesis inhibitor) under & $\mathrm{LL}+\mathrm{AOA}$ \\
low light & \\
\hline
\end{tabular}

After the treatments, expanded leaves of plants were randomly sampled and immediately frozen in liquid nitrogen, and stored at $-80^{\circ} \mathrm{C}$ for physiological and biochemical analysis. Fresh leaves were used for gas exchange and $\mathrm{Chl}$ fluorescence experiments.

Growth characteristics: Plant heights were measured with a ruler, while a vernier caliper was used to measure leaf widths, and total tiller number per seedling was individually counted. Three seedlings from each treatment were taken after removing the quartz sand and transferred to an oven at $80^{\circ} \mathrm{C}$ for $72 \mathrm{~h}$. Dry mass was determined from each treatment until a constant mass was obtained. Turf quality was used to evaluate overall health and vigor of turfgrass based on color, density, and uniformity. It was given a score in 1-9 scale, where 1 denotes the worst and 9 indicates the best in all evaluation criteria (Zhang et al. 2017).

Photosynthetic pigment content: $\mathrm{Chl}$ and Car production in fresh leaves was determined using the method of Lichtenthaler (1987) with slight modifications. Leaves weighing approximately $0.1 \mathrm{~g}$ were used to extract Chl and Car by soaking in a blank solvent containing $10 \mathrm{~mL}$ of $80 \%$ acetone and $5 \mathrm{~mL}$ of $95 \%$ ethyl alcohol for $24 \mathrm{~h}$ in dark. Absorbance of the extracts was measured at 440, 663, and $645 \mathrm{~nm}$ spectrophotometrically ( $L V-1800, M A P A D A$ Co., Ltd., Shanghai, China). Chl $a, \mathrm{Chl} b, \mathrm{Chl}(a+b)$, and Car concentrations were calculated using the equations and 
extinction coefficients provided by Lichtenthaler (1987). The Chl $a / b$ ratio was computed by dividing the concentration of Chl $a$ by that of Chl $b$.

Gas-exchange parameters: Net photosynthetic rate $\left(P_{\mathrm{N}}\right)$, stomatal conductance $\left(g_{\mathrm{s}}\right)$, intercellular $\mathrm{CO}_{2}$ concentration $\left(C_{\mathrm{i}}\right)$, and transpiration rate $(E)$ were measured using a portable photosynthesis system (Li-6400, LICOR, Inc., Lincoln, NE) from 8:30 to 11:30 h. To achieve full photosynthetic induction, all tall fescue seedlings were illuminated with $800 \mu \mathrm{mol} \mathrm{m}{ }^{-2} \mathrm{~s}^{-1}$ of saturated PPFD for $30 \mathrm{~min}$ prior to measurement (Mittler et al. 2001). $P_{\mathrm{N}}, g_{\mathrm{s}}, C_{\mathrm{i}}$, and $E$ were monitored on the third fully expanded leaves from the top. During the process, ambient air temperature, relative humidity, and $\mathrm{CO}_{2}$ concentration were maintained at $25^{\circ} \mathrm{C}, 60 \%$, and $400 \mu \mathrm{mol} \mathrm{mol}{ }^{-1}$, respectively.

Chl fluorescence on the same leaf was measured using a portable pulse-amplitude-modulated fluorometer (PAM 2500, Walz, Effeltrich, Germany) with PamWin software as described by Oliveira and Peñuelas (2004). The third completely expanded leaves from the top were kept in dark using a leaf clip for at least $20 \mathrm{~min}$ of adaptation before measurement. $F_{0}$ was monitored using a weak modulated light irradiation which was low enough to not induce fluorescence at room temperature, while $F_{m}$ was determined by 0.8 -s saturation pulse flash at PPFD of $4,000 \mu \mathrm{mol} \mathrm{m} \mathrm{m}^{-2} \mathrm{~s}^{-1}$. The leaf was illuminated with constant actinic light to determine $\mathrm{F}_{\mathrm{s}}$, after which a second saturation pulse was applied to determine $\mathrm{F}_{\mathrm{m}}{ }^{\prime}$ in light-adapted state. Then actinic light was removed, and far-red light was turned on for several seconds to record the minimum fluorescence of light-adapted leaves $\left(\mathrm{F}_{0}{ }^{\prime}\right)$. Afterwards, $\mathrm{F}_{\mathrm{v}} / \mathrm{F}_{\mathrm{m}}=\left[\left(\mathrm{F}_{\mathrm{m}}-\mathrm{F}_{0}\right) / \mathrm{F}_{\mathrm{m}}\right], \Phi_{\text {PSII }}=\left[\left(\mathrm{F}_{\mathrm{m}}{ }^{\prime}-\mathrm{F}_{\mathrm{s}}\right) / \mathrm{F}_{\mathrm{m}}{ }^{\prime}\right]$, $\mathrm{ETR}=\left(\Phi_{\mathrm{PSII}} \times \mathrm{PPFD} \times 0.5\right)$, and $\mathrm{q}_{\mathrm{P}}=\left[\Delta \mathrm{F}^{\prime} /\left(\mathrm{F}_{\mathrm{m}}{ }^{\prime}-\mathrm{F}_{0}{ }^{\prime}\right)\right]$ were computed, respectively. For ETR and $\mathrm{q}_{\mathrm{P}}$ calculation, 0.5 is a partition coefficient of energy between PSI and PSII. Leaf Chl fluorescence was determined simultaneously with leaf gas exchange on the same area of leaf at the day of gas-exchange measurement (Lu et al. 2003).

Total soluble sugar production: Total soluble sugar concentration was measured according to the method described by $\mathrm{Xu}$ et al. (2013). Fresh leaves $(0.5 \mathrm{~g})$ were grinded with a pestle in an icy mortar, and mixed with $5 \mathrm{~mL}$ of distilled water, immediately followed by incubating in boiling water for $30 \mathrm{~min}$. After centrifugation at $4,000 \times \mathrm{g}$ for $5 \mathrm{~min}$ and a removal of supernatant, pellet was resuspended and reextracted twice. Three supernatants were transferred to $25-\mathrm{mL}$ volumetric flask and distilled water was added to make up the volume. Afterwards, $1 \mathrm{~mL}$ of sample extract was added to $3 \mathrm{~mL}$ of anthrone reagent and mixed well. After heating the sample at $100^{\circ} \mathrm{C}$ for $10 \mathrm{~min}$ and cooling down, soluble sugar content was measured at the absorbance of $620 \mathrm{~nm}(L V-1800$, MAPADA Co., Ltd., Shanghai, China).

Soluble protein content: Total soluble protein contents in leaves of stressed or non-stressed seedlings were determined using modified method of Bradford (1976).
Leaves $(0.3 \mathrm{~g})$ were crushed in phosphate buffer $(\mathrm{pH} 7.0)$. The homogenate was centrifuged at $12,000 \times g$ for $10 \mathrm{~min}$. All steps were performed at $4^{\circ} \mathrm{C}$. One $\mathrm{mL}$ of sample extract was added to $5 \mathrm{~mL}$ of $0.01 \%(\mathrm{w} / \mathrm{v})$ Coomassie Brilliant Blue $G-250$ containing $4.7 \%(\mathrm{w} / \mathrm{v})$ ethanol and $8.5 \%(\mathrm{w} / \mathrm{v})$ phosphoric acid, and mixed well. After incubation at room temperature for $2 \mathrm{~min}$, absorbance was recorded at $595 \mathrm{~nm}$ (LV-1800, MAPADA Co., Ltd., Shanghai, China). Concentration of protein was calculated by standard curve using different concentrations of bovine serum albumin (BSA) and expressed as $\mathrm{mg} \mathrm{g}^{-1}(\mathrm{FM})$.

Analysis of Rubisco enzyme activity: Rubisco activity was determined according to the method of Lilley and Walker (1974) with slight modifications. Samples (0.3 g) were crushed with a pestle in an ice-cold mortar $\left(4^{\circ} \mathrm{C}\right)$ using a small amount of quartz sand and $1.5 \mathrm{~mL}$ of extraction buffer containing $40 \mathrm{mM}$ Tris- $\mathrm{HCl}(\mathrm{pH} 7.6)$, $10 \mathrm{mM} \mathrm{MgCl}, 0.25 \mathrm{mM}$ EDTA, and $5.0 \mathrm{mM}$ glutathione. Afterwards, the homogenate was centrifuged at $12,000 \times g$ for $20 \mathrm{~min}$ at $4^{\circ} \mathrm{C}$ and supernatant was collected for the measurement of Rubisco activity. Sample extract $(50 \mu \mathrm{L})$ was added to $900 \mu \mathrm{L}$ of reaction volume consisting of $50 \mathrm{mM}$ Tris- $\mathrm{HCl}$ (pH 7.8), 12 mM MgCl, 0.4 mM EDTA, $5 \mathrm{mM}$ ATP, $5 \mathrm{mM}$ NADH, 5 units of glyceraldehyde3-phosphate dehydrogenase, 5 units of 3-phosphoglyceric phosphokinase, 17.5 units of creatine phosphokinase, and the reaction was initiated by adding $50 \mu \mathrm{L}$ of $10 \mathrm{mM}$ RuBP. Absorbance was measured at $340 \mathrm{~nm}$ ( $L V-1800, M A P A D A$ Co., Ltd., Shanghai, China) every $10 \mathrm{~s}$ for $3 \mathrm{~min}$ corresponding to the oxidation of NADH. Extraction buffer was used to replace RuBP as a blank. The decrease of absorbance with the blank and the differences were used to determine the enzyme activity. according to the formulas: Rubisco activity [nmol(NADH) $\mathrm{min}^{-1} \mathrm{mg}^{-1}$ (protein)] = $\Delta \mathrm{A} / \Delta \mathrm{t} \times \mathrm{N} \times 109 /\left(\varepsilon \times \mathrm{d} \times \mathrm{C}_{\mathrm{pr}}\right)$, where $\Delta \mathrm{A} / \Delta \mathrm{t}$ represents the change of optical density at $340 \mathrm{~nm}$ per min, $\mathrm{N}$ denotes the ratio of the extraction volume to the reaction volume, $\varepsilon$ means the molar extinction coefficient of NADH at $340 \mathrm{~nm}, \mathrm{~d}$ is the optical distance of the cuvette, and $\mathrm{C}_{\mathrm{pr}}$ represents the concentration of soluble protein in extraction solution.

Determination of lipid peroxidation: Membrane lipid peroxidation was determined by malondialdehyde (MDA) content using trichloroacetic acid method of Buege and Aust (1978). Fresh leaves (0.5 g) were grinded with pestle in a prechilled mortar containing a quartz sand and homogenized in $10 \mathrm{~mL}$ of $10 \%(\mathrm{w} / \mathrm{v})$ trichloroacetic acid, immediately followed by centrifugation at $12,000 \times g$ for $10 \mathrm{~min}$ and supernatant was collected as sample extract. Two $\mathrm{mL}$ of supernatant and $2 \mathrm{~mL}$ of mixture containing $10 \%$ trichloroacetic acid and $0.5 \%$ thiobarbituric acid were mixed well, and the solution was incubated in a boiling water bath for $15 \mathrm{~min}$. Samples were refrigerated immediately and centrifuged again at $12,000 \times g$ at $4^{\circ} \mathrm{C}$ for $10 \mathrm{~min}$. The absorption of supernatant was recorded at 450, 532, and $600 \mathrm{~nm}$ using a spectrophotometer ( $\mathrm{LV}$ 1800, MAPADA Co., Ltd., Shanghai, China). 
Quantification of antioxidant enzymatic activity: Approximately $1.0 \mathrm{~g}$ of fresh leaves was finely homogenized with a mortar and pestle on ice in $5 \mathrm{~mL}$ of a solution containing $50 \mathrm{mM}$ phosphate buffer $(\mathrm{pH} 7.8)$, $1 \mathrm{mM}$ EDTA and $2 \%(\mathrm{w} / \mathrm{v})$ polyvinylpolypyrrolidone. The homogenate was centrifuged at $12,000 \times g$ at $4^{\circ} \mathrm{C}$ for 20 min and supernatant was collected for measuring enzyme activities (Zhou et al. 2005). The spectrophotometer $L V$ 1800 (MAPADA Co., Ltd., Shanghai, China) was used for following measurements.

Peroxidase (POD, EC 1.11.1.7) activity was analyzed as described by Upadhyaya et al. (1985) based on its capability to convert guaiacol to tetraguaiacol. Each POD reaction system was composed of $2.5 \mathrm{~mL}$ of $50 \mathrm{mM}$ potassium phosphate buffer ( $\mathrm{pH} 6.1), 1.0 \mathrm{~mL}$ of $1 \%(\mathrm{v} / \mathrm{v})$ $\mathrm{H}_{2} \mathrm{O}_{2}$, and $1.0 \mathrm{~mL}$ of $1 \%(\mathrm{v} / \mathrm{v})$ guaiacol followed by the addition of $10 \mathrm{~mL}$ of enzyme extract to initiate the reaction. Changes of absorption were determined at $420 \mathrm{~nm}$ within 3 min after the beginning of the reaction in 1-min interval. One unit of POD activity was defined as $1 \mu \mathrm{mol}\left(\mathrm{H}_{2} \mathrm{O}_{2}\right.$ decomposed) $\mathrm{mL}^{-1} \mathrm{~min}^{-1}$.

Superoxide dismutase (SOD, EC 1.15.1.1) activity was measured following the photochemical nitroblue tetrazolium (NBT) method as described by Beauchamp and Fridovich (1971). Three $\mathrm{mL}$ of reaction mixture consisted of $13 \mu \mathrm{M}$ methionine, $63 \mu \mathrm{M}$ NBT, $1.3 \mu \mathrm{M}$ riboflavin, $50 \mathrm{mM}$ phosphate buffer ( $\mathrm{pH} 7.8)$, and enzyme extract. One unit of SOD was defined as the amount of enzyme per fresh mass sample inhibiting the photochemical reduction of NBT by $50 \%$. Absorbance at $560 \mathrm{~nm}$ of $1-\mathrm{cm}$ cuvette was monitored. One unit of SOD was defined as the amount of enzyme per protein inhibiting the photochemical reduction of NBT by $50 \%$.

Ascorbate peroxidase (APX, EC 1.11.1.11) activity was measured by monitoring the rate of ascorbic acid oxidation according to the method of Nakano and Asada (1981). Three $\mathrm{mL}$ of APX assay mixture consisted of $100 \mathrm{mM}$ phosphate ( $\mathrm{pH} 7.0), 0.1 \mathrm{mM}$ EDTA-Na, $0.3 \mathrm{mM}$ ascorbic acid, $0.06 \mathrm{mM} \mathrm{H}_{2} \mathrm{O}_{2}$, and $100 \mu \mathrm{L}$ of enzyme extract. The oxidation of ascorbate was observed by the decrease in absorption at $290 \mathrm{~nm}$ after adding enzyme extract. One unit of APX forms $1 \mu \mathrm{M}$ of ascorbate acid oxidized per min under assay conditions.

Endogenous $\mathrm{H}_{2} \mathrm{~S}$ concentration was determined by the conversion of methylene blue from dimethyl- $p$-phenylenediamine in $\mathrm{H}_{2} \mathrm{SO}_{4}$ according to the method described by Chen et al. (2011) with some slight modifications. Leaves $(0.5 \mathrm{~g})$ of experimental plants were grinded on ice and mixed in $5 \mathrm{~mL}$ of $50 \mathrm{mM}$ phosphate buffer solution ( $\mathrm{pH} 6.8$ ) including $0.1 \mathrm{M}$ EDTA and $0.2 \mathrm{M}$ ascorbic acid. Homogenate was mixed in a test tube containing $0.5 \mathrm{~mL}$ of $1 \mathrm{M} \mathrm{HCl}$ to emit $\mathrm{H}_{2} \mathrm{~S}$ at room temperature, and the released $\mathrm{H}_{2} \mathrm{~S}$ was absorbed in $1 \%(\mathrm{w} / \mathrm{v})$ zinc acetate $(0.5 \mathrm{~mL})$ trap at the bottom of the test tube. After $30 \mathrm{~min}$ of reaction, $0.3 \mathrm{~mL}$ of $5 \mathrm{mM}$ dimethyl- $p$-phenylenediamine dissolved in $3.5 \mathrm{mM} \mathrm{H}_{2} \mathrm{SO}_{4}$ was added to the trap, immediately followed by injecting $0.3 \mathrm{ml}$ of $50 \mathrm{mM}$ ferric ammonium sulphate in $100 \mathrm{mM} \mathrm{H}_{2} \mathrm{SO}_{4}$ into the trap. After incubating the mixture for $15 \mathrm{~min}$ at room temperature, the mass of $\mathrm{H}_{2} \mathrm{~S}$ was measured spectrophotometrically at $667 \mathrm{~nm}$ (LV-1800, MAPADA Co., Ltd., Shanghai, China). Blanks were prepared by same procedures with unused zinc acetate solution.

Statistical analysis: The experiments were designed in a completely randomized design. Three replicates were performed for each experiment. All values were expressed as means $\pm \mathrm{SD}$. Statistical analyses were performed by SPSS 22 software (IBM Corp., Chicago, IL, USA). Data were evaluated by Shapiro-Wilk's test to verify normality and Levene's test to verify homoscedasticity. Then, they were analyzed by one-way analysis of variance $(A N O V A)$ followed by Duncan's multiple range tests at $p<0.05$. All figures were drawn using the SigmaPlot software (version 12.5, SYSTAT Software Inc., Richmond, CA, USA).

\section{Results}

Optimal concentration of NaHS: Since the effects of $\mathrm{H}_{2} \mathrm{~S}$ on plants are concentration dependent, seedlings were supplied with different concentrations of NaHS (100, 300, $500 ; 1,000$; and $1,500 \mu \mathrm{M}$ ) for $7 \mathrm{~d}$ to determine the optimal concentration. Results showed that $500 \mu \mathrm{M}$ of NaHS significantly increased turf quality, dry mass, Chl content, and alleviated MDA content. Hereafter, $500 \mu \mathrm{M}$ of NaHS was used in the following experiments as $\mathrm{H}_{2} \mathrm{~S}$ donor (Table 1).

Growth and morphology: Significant differences were observed in the growth and morphology parameters of tall fescue among all treatments. The growth after $7 \mathrm{~d}$ under LL stress was found to be suppressed, showing a reduction in plant height, leaf width, tiller number, dry mass, and turf quality of tall fescue by $23.2,18.5,30.4,57.6$, and $42.1 \%$, respectively, compared with the control plants. In addition, exogenous application of $\mathrm{H}_{2} \mathrm{~S}$ partially reversed the impacts of LL stress. Application of exogenous $\mathrm{H}_{2} \mathrm{~S}$ significantly increased plant height, leaf width, tiller number, dry mass, and turf quality of tall fescue by 14.4, 11.4, 31.3, 48.0, and $22.7 \%$, respectively. Further, under LL stress, treating plants with $\mathrm{HT}\left(\mathrm{H}_{2} \mathrm{~S}\right.$ scavenger $)$ decreased the plant height, leaf width, tiller number, dry mass, and turf quality of tall fescue compared to LL stress alone. Similarly, treatment with AOA ( $\mathrm{H}_{2} \mathrm{~S}$-biosynthesis inhibitor) also significantly reduced above-mentioned parameters when compared to LL stress seedlings (Table 2).

Photosynthetic pigment contents: After $7 \mathrm{~d}$ of growth under LL stress, concentrations of Chl $a, \mathrm{Chl} b, \mathrm{Chl}(a+b)$, and Car decreased by 35.0,29.1,33.7, and 33.9\%, respectively, when compared with the control seedlings (Table 3 ). Moreover, diminution of contents of $\mathrm{Chl} a, \mathrm{Chl} b$, Chl $(a+b)$, and Car were significantly eliminated when leaves of tall fescue were treated with exogenous $\mathrm{H}_{2} \mathrm{~S}$. However, the application of HT or AOA evidently reduced the production of $\mathrm{Chl} a, \mathrm{Chl} b, \mathrm{Chl}(a+b)$, and Car under LL stress (Table 3).

Gas-exchange parameters: When leaves of tall fescue 
Table 1. Effects of different NaHS concentrations $(0,100,300,500 ; 1,000$; and 1,500 $\mu \mathrm{M})$ on low light (LL) stress-induced changes in turf quality, dry mass, Chl content, and malondialdehyde (MDA) content in leaves of tall fescue seedlings at $7 \mathrm{~d}$ after treatments. $\mathrm{CK}$ - treatment with distilled water; LL - treatment with distilled water under LL; LL + 100 - treatment with $100 \mu \mathrm{M}$ NaHS under LL; $\mathrm{LL}+300$ - treatment with $300 \mu \mathrm{M}$ NaHS under LL; LL + 500 - treatment with $500 \mu \mathrm{M}$ NaHS under LL; LL + 1,000 - treatment with $1,000 \mu \mathrm{M}$ NaHS under LL; LL + 1,500 - treatment with 1,500 $\mu \mathrm{M}$ NaHS under LL. Each value is the mean \pm SD of three replicates $(n=3)$. Means marked with different letters indicate statistically significant differences according to Duncan's multiple range tests $(p<0.05)$.

\begin{tabular}{|c|c|c|c|c|}
\hline Treatment & Turf quality & Dry mass [g per plant] & $\operatorname{Chl}(a+b)\left[\mathrm{mg} \mathrm{g}^{-1}(\mathrm{FM})\right]$ & MDA $\left[\mathrm{nmol} \mathrm{g}^{-1}(\mathrm{FM})\right]$ \\
\hline $\mathrm{CK}$ & $8.07 \pm 0.13^{\mathrm{a}}$ & $0.59 \pm 0.08^{a}$ & $3.36 \pm 0.06^{\mathrm{a}}$ & $2.29 \pm 0.39^{\mathrm{c}}$ \\
\hline LL & $4.67 \pm 0.13^{\mathrm{cd}}$ & $0.25 \pm 0.06^{\mathrm{c}}$ & $2.23 \pm 0.01^{\mathrm{d}}$ & $3.40 \pm 0.13^{\mathrm{a}}$ \\
\hline $\mathrm{LL}+100$ & $4.93 \pm 0.07^{\mathrm{c}}$ & $0.27 \pm 0.02^{\mathrm{c}}$ & $2.32 \pm 0.16^{\mathrm{d}}$ & $3.31 \pm 0.17^{\mathrm{a}}$ \\
\hline $\mathrm{LL}+300$ & $5.40 \pm 0.12^{\mathrm{b}}$ & $0.33 \pm 0.02^{\mathrm{bc}}$ & $2.65 \pm 0.18^{\mathrm{bc}}$ & $3.15 \pm 0.09^{\mathrm{a}}$ \\
\hline $\mathrm{LL}+500$ & $5.73 \pm 0.24^{\mathrm{b}}$ & $0.37 \pm 0.02^{\mathrm{b}}$ & $2.80 \pm 0.11^{\mathrm{b}}$ & $2.91 \pm 0.14^{\mathrm{b}}$ \\
\hline $\mathrm{LL}+1,000$ & $4.27 \pm 0.13^{\mathrm{d}}$ & $0.30 \pm 0.01^{\mathrm{bc}}$ & $2.53 \pm 0.06^{\mathrm{c}}$ & $2.99 \pm 0.06^{\mathrm{b}}$ \\
\hline $\mathrm{LL}+1,500$ & $3.80 \pm 0.12^{\mathrm{e}}$ & $0.28 \pm 0.03^{\mathrm{bc}}$ & $2.27 \pm 0.03^{\mathrm{d}}$ & $3.16 \pm 0.13^{\mathrm{a}}$ \\
\hline
\end{tabular}

Table 2. Effects of exogenous $\mathrm{H}_{2} \mathrm{~S}$ on low light (LL) stress-induced changes in plant height, leaf width, tiller number, dry mass, and turf quality in leaves of tall fescue seedlings at $7 \mathrm{~d}$ after treatments. CK - treatment with distilled water; LL - treatment with distilled water under LL; LL + NaHS - treatment with $500 \mu \mathrm{M}$ NaHS under LL; LL + HT - treatment with $300 \mu \mathrm{M}$ hypotaurine under LL; $\mathrm{LL}+\mathrm{AOA}$ - treatment with $300 \mu \mathrm{M}$ aminooxy acetic acid under LL. Each value is the mean $\pm \mathrm{SD}$ of three replicates $(n=3)$. Means marked with different letters indicate statistically significant differences according to Duncan's multiple range tests $(p<0.05)$.

\begin{tabular}{llllll}
\hline Treatment & Plant height $[\mathrm{cm}]$ & Leaf width $[\mathrm{mm}]$ & Tiller number & Dry mass [g per plant] Turf quality \\
\hline CK & $22.08 \pm 1.04^{\mathrm{a}}$ & $5.88 \pm 0.24^{\mathrm{a}}$ & $4.60 \pm 0.40^{\mathrm{a}}$ & $0.59 \pm 0.08^{\mathrm{a}}$ & $8.07 \pm 0.13^{\mathrm{a}}$ \\
LL & $16.94 \pm 0.71^{\mathrm{c}}$ & $4.79 \pm 0.14^{\mathrm{c}}$ & $3.20 \pm 0.20^{\mathrm{b}}$ & $0.25 \pm 0.06^{\mathrm{bc}}$ & $4.67 \pm 0.13^{\mathrm{c}}$ \\
LL + NaHS & $19.38 \pm 0.28^{\mathrm{b}}$ & $5.34 \pm 0.10^{\mathrm{b}}$ & $4.20 \pm 0.37^{\mathrm{a}}$ & $0.37 \pm 0.02^{\mathrm{b}}$ & $5.73 \pm 0.24^{\mathrm{b}}$ \\
LL + HT & $14.50 \pm 0.73^{\mathrm{d}}$ & $3.87 \pm 0.22^{\mathrm{d}}$ & $2.40 \pm 0.24^{\mathrm{c}}$ & $0.14 \pm 0.02^{\mathrm{d}}$ & $2.60 \pm 0.12^{\mathrm{d}}$ \\
LL + AOA & $13.30 \pm 0.93^{\mathrm{d}}$ & $4.22 \pm 0.08^{\mathrm{d}}$ & $2.60 \pm 0.24^{\mathrm{c}}$ & $0.20 \pm 0.01^{\mathrm{c}}$ & $3.13 \pm 0.35^{\mathrm{d}}$ \\
\hline
\end{tabular}

Table 3. Effects of exogenous $\mathrm{H}_{2} \mathrm{~S}$ on low light (LL) stress-induced changes in chlorophyll (Chl) and carotenoids (Car) contents in leaves of tall fescue leaves seedlings at $7 \mathrm{~d}$ after treatments. $\mathrm{CK}$ - treatment with distilled water; LL - treatment with distilled water under $\mathrm{LL}$; LL + NaHS - treatment with $500 \mu \mathrm{M}$ NaHS under LL; LL + HT - treatment with $300 \mu \mathrm{M}$ hypotaurine under LL; LL + AOA treatment with $300 \mu \mathrm{M}$ aminooxy acetic acid under LL. Each value is the mean $\pm \mathrm{SD}$ of three replicates $(n=3)$. Means marked with different letters indicate statistically significant differences according to Duncan's multiple range tests $(p<0.05)$.

\begin{tabular}{llllll}
\hline Treatment & Chl $a\left[\mathrm{mg} \mathrm{g}^{-1}(\mathrm{FM})\right]$ & $\mathrm{Chl} b\left[\mathrm{mg} \mathrm{g}^{-1}(\mathrm{FM})\right]$ & $\mathrm{Chl}(a+b)\left[\mathrm{mg} \mathrm{g}^{-1}(\mathrm{FM})\right]$ & $\mathrm{Chl} a / b$ & $\mathrm{Car}\left[\mathrm{mg} \mathrm{g}^{-1}(\mathrm{FM})\right]$ \\
\hline CK & $2.57 \pm 0.10^{\mathrm{a}}$ & $0.79 \pm 0.04^{\mathrm{a}}$ & $3.36 \pm 0.06^{\mathrm{a}}$ & $3.25 \pm 0.05^{\mathrm{a}}$ & $1.27 \pm 0.07^{\mathrm{a}}$ \\
LL & $1.67 \pm 0.03^{\mathrm{c}}$ & $0.56 \pm 0.02^{\mathrm{c}}$ & $2.23 \pm 0.01^{\mathrm{c}}$ & $3.00 \pm 0.04^{\mathrm{ab}}$ & $0.84 \pm 0.02^{\mathrm{c}}$ \\
LL + NaHS & $2.13 \pm 0.12^{\mathrm{b}}$ & $0.67 \pm 0.01^{\mathrm{b}}$ & $2.80 \pm 0.11^{\mathrm{b}}$ & $3.17 \pm 0.04^{\mathrm{a}}$ & $1.02 \pm 0.01^{\mathrm{b}}$ \\
LL + HT & $1.30 \pm 0.08^{\mathrm{d}}$ & $0.46 \pm 0.01^{\mathrm{d}}$ & $1.76 \pm 0.08^{\mathrm{d}}$ & $2.82 \pm 0.15^{\mathrm{b}}$ & $0.71 \pm 0.01^{\mathrm{d}}$ \\
LL + AOA & $1.34 \pm 0.10^{\mathrm{d}}$ & $0.48 \pm 0.03^{\mathrm{d}}$ & $1.81 \pm 0.07^{\mathrm{d}}$ & $2.80 \pm 0.15^{\mathrm{b}}$ & $0.72 \pm 0.02^{\mathrm{d}}$ \\
\hline
\end{tabular}

were exposed to LL regime for $7 \mathrm{~d}$, gas-exchange parameters including $P_{\mathrm{N}}, g_{\mathrm{s}}$, and $E$ were reduced by $50.8,63.0$, and $80.7 \%$, respectively, when compared with control seedlings. Moreover, treatment of plants with exogenous $\mathrm{H}_{2} \mathrm{~S}$ significantly increased $P_{\mathrm{N}}, g_{\mathrm{s}}$, and $E$ in leaves of tall fescue when compared to LL treatment alone. However, the application of exogenous $\mathrm{H}_{2} \mathrm{~S}$ significantly reduced $C_{\mathrm{i}}$ by $9.2 \%$ compared to LL treatment alone. Further, when endogenous $\mathrm{H}_{2} \mathrm{~S}$ was scavenged (HT addition), $C_{\mathrm{i}}$ value increased significantly (Fig. 1).

Chl fluorescence parameters: Compared to control plants, seedlings grown in LL showed lower $\mathrm{F}_{\mathrm{v}} / \mathrm{F}_{\mathrm{m}}, \Phi_{\mathrm{PSII}}, \mathrm{q}_{\mathrm{P}}$, and
ETR values with significant differences throughout the experimental period. In addition, when compared to LL treatment only, significant increments of $3.8,12.5,16.1$, and $24.5 \%$ were recorded in the values of $F_{v} / F_{m}, \Phi_{\text {PSII }}, q_{p}$, and ETR, respectively, under exogenous $\mathrm{H}_{2} \mathrm{~S}$ treatment. However, plants supplied with HT showed reduced fluorescence parameters and the variation trend was similar to that of AOA-treated plants (Fig. 2).

Total soluble sugar content: After $7 \mathrm{~d}$ of LL treatment, severe inhibition was observed in the total soluble sugar content of leaves of tall fescue seedlings, in contrast with the control plants. In addition, exogenous $\mathrm{H}_{2} \mathrm{~S}$ treatment 

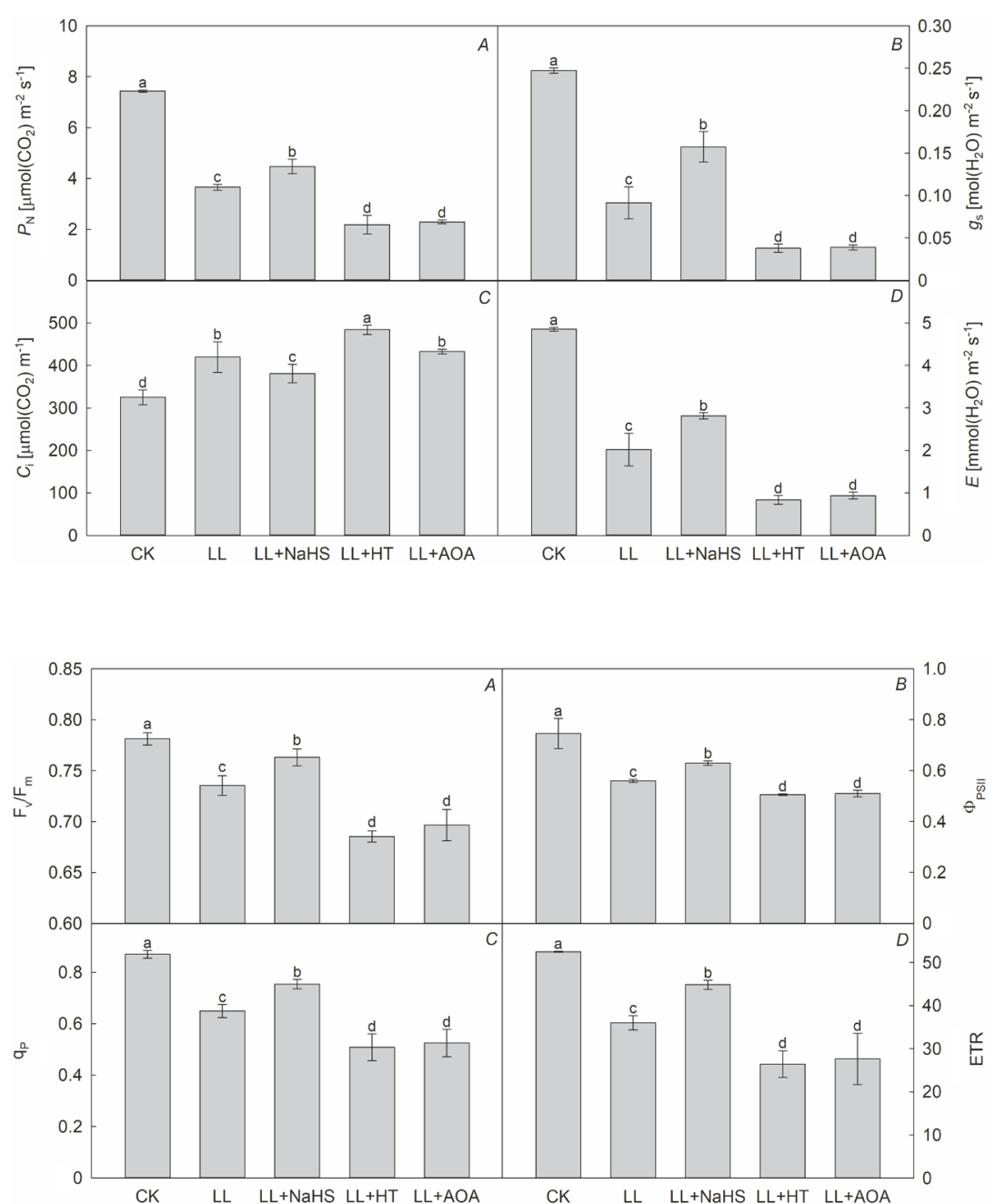

Fig. 1. Effects of exogenous $\mathrm{H}_{2} \mathrm{~S}$ on low light stress-induced changes in the net photosynthetic rate $\left(P_{\mathrm{N}}\right)(A)$, stomatal conductance $\left(g_{\mathrm{s}}\right)(B)$, intercellular $\mathrm{CO}_{2}$ concentration $\left(C_{\mathrm{i}}\right)(C)$, and transpiration rate $(E)(D)$ in leaves of tall fescue seedlings at $7 \mathrm{~d}$ after treatments. CK treatment with distilled water; LL - treatment with distilled water under LL; LL + NaHS treatment with $500 \mu \mathrm{M}$ NaHS under LL; LL $+\mathrm{HT}$ - treatment with $300 \mu \mathrm{M}$ hypotaurine under LL; LL + AOA - treatment with 300 $\mu \mathrm{M}$ aminooxy acetic acid under LL. Each histogram denotes a mean value of three replicates and vertical bars represent SD ( $n$ $=3$ ). Means marked with different letters above the bars indicate statistically significant differences according to Duncan's multiple range tests.

Fig. 2. Effects of exogenous $\mathrm{H}_{2} \mathrm{~S}$ on low light stress-induced changes in maximal quantum yield of PSII photochemistry $\left(\mathrm{F}_{\mathrm{v}} / \mathrm{F}_{\mathrm{m}}\right)(A)$, effective quantum yield of PSII photochemistry $\left(\Phi_{\mathrm{PSII}}\right)(B)$, photochemical quenching coefficient $\left(\mathrm{q}_{\mathrm{p}}\right)(C)$, and electron transport rate (ETR) $(D)$ in leaves of tall fescue seedlings at 7 $\mathrm{d}$ after treatments. $\mathrm{CK}$ - treatment with distilled water; $\mathrm{LL}$ - treatment with distilled water under LL; LL + NaHS - treatment with $500 \mu \mathrm{M} \mathrm{NaHS}$ under LL; LL + HT - treatment with $300 \mu \mathrm{M}$ hypotaurine under LL; LL + AOA - treatment with $300 \mu \mathrm{M}$ aminooxy acetic acid under LL. Each histogram denotes a mean value of three replicates and vertical bars represent $\operatorname{SD}(n=3)$. Means marked with different letters above the bars indicate statistically significant differences according to Duncan's multiple range tests. significantly improved the accumulation of soluble sugar content in leaves when compared with LL stress only. Further, the application of HT or AOA did not significantly affect total soluble sugar content in tall fescue leaves, compared to the LL-stressed seedlings only (Fig. 3A).

Soluble protein content was significantly reduced in leaves of tall fescue subjected to LL stress, compared with the control plants. Moreover, an increase of soluble protein concentration was observed in LL-treated leaves with exogenous $\mathrm{H}_{2} \mathrm{~S}$ application. However, HT or AOA addition was found to decrease soluble protein concentration in plants when compared with LL treatment alone (Fig. 3B).

Activities of Rubisco enzyme: Value of Rubisco activity of tall fescue in LL was lower than those in the control plants. However, photosynthetic enzyme activity inhibition was considerably ceased by the application of exogenous $\mathrm{H}_{2} \mathrm{~S}$ under LL conditions. Further, compared to LL treatment only, when endogenous $\mathrm{H}_{2} \mathrm{~S}$ was scavenged or endogenous $\mathrm{H}_{2} \mathrm{~S}$ biosynthesis was inhibited, Rubisco activity of tall fescue leaves was significantly reduced (Fig. 3C).

Membrane lipid peroxidation: When compared with control seedlings, MDA accumulation significantly increased by $48.6 \%$ in tall fescue after $7-\mathrm{d}$ LL treatment. In addition, the decreasing MDA content was found when tall fescue leaves were supplied with exogenous $\mathrm{H}_{2} \mathrm{~S}$, compared to the LL stress alone. However, MDA was remarkably enhanced in tall fescue leaves treated with HT or AOA, respectively (Fig. 4A).

Activities of antioxidant enzymes: LL stress showed significant increment in the activity of POD in tall fescue leaves when compared with control plants. The treatment of tall fescue seedlings with exogenous $\mathrm{H}_{2} \mathrm{~S}$ remarkably increased POD activity with significant difference when compared to LL treatment alone. The response was reversed in POD activity of tall fescue leaves treated with HT or AOA (Fig. 4B).

Compared to control seedlings, a significant increase of SOD activity was found in LL-stressed tall fescue leaves. In addition, application of exogenous $\mathrm{H}_{2} \mathrm{~S}$ evidently increased the activity of SOD. Further, treating plants with HT or AOA greatly reduced SOD activity of tall fescue seedlings, compared with LL-stressed plants (Fig. 4C).

After $7 \mathrm{~d}$ of growth under LL stress, the activity of APX was remarkably enhanced in leaves of tall fescue 


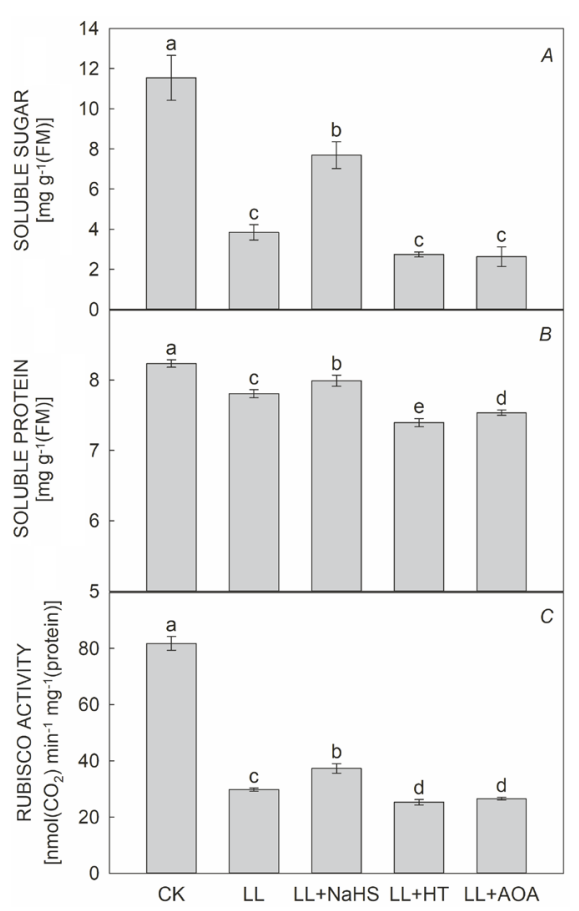

Fig. 3. Effects of exogenous $\mathrm{H}_{2} \mathrm{~S}$ on low light stress-induced changes in soluble sugar $(A)$, soluble protein $(B)$, and Rubisco activity $(C)$ in leaves of tall fescue seedlings at $7 \mathrm{~d}$ after treatments. $\mathrm{CK}$ - treatment with distilled water; $\mathrm{LL}$ - treatment with distilled water under LL; LL + NaHS - treatment with $500 \mu \mathrm{M}$ NaHS under LL; LL + HT - treatment with $300 \mu \mathrm{M}$ hypotaurine under LL; LL + AOA - treatment with $300 \mu \mathrm{M}$ aminooxy acetic acid under LL. Each histogram denotes a mean value of three replicates and vertical bars represent $\mathrm{SD}(n=3)$. Means marked with different letters above the bars indicate statistically significant differences according to Duncan's multiple range tests.

plants. Moreover, when compared to LL treatment only, exogenous $\mathrm{H}_{2} \mathrm{~S}$ treatment significantly improved the activity of APX. However, plants applied with HT or AOA showed decreased APX activity, compared with the LLstressed seedlings alone (Fig. 4D).

Endogenous $\mathrm{H}_{2} \mathrm{~S}$ concentration: To explore the potential role of endogenous $\mathrm{H}_{2} \mathrm{~S}$ in response to LL stress of tall

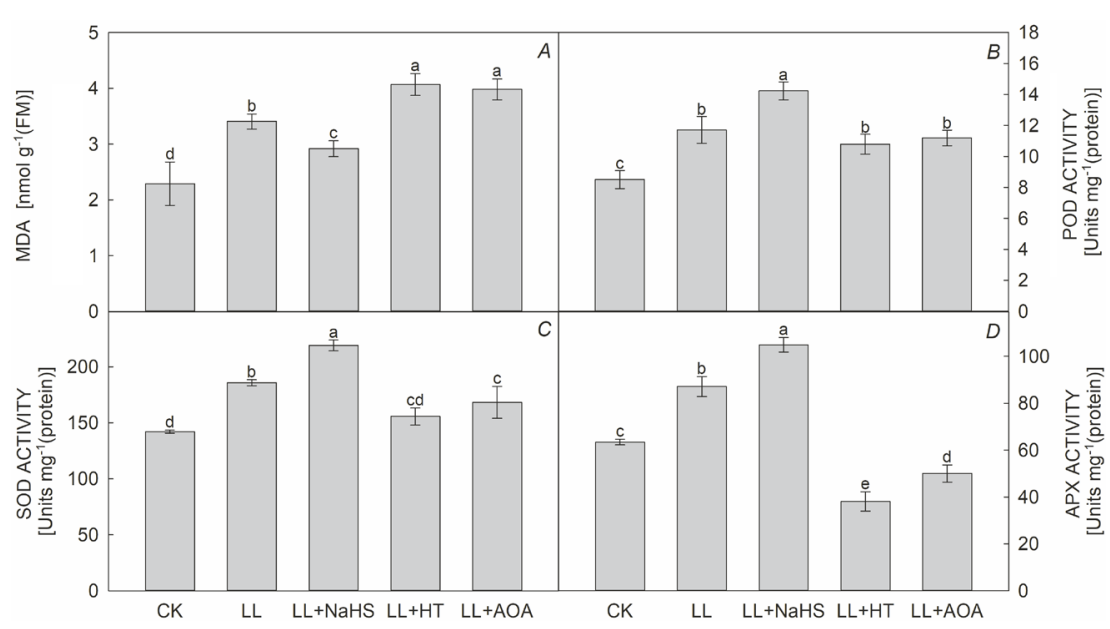

fescue, $\mathrm{H}_{2} \mathrm{~S}$ contents of leaves were measured. Tall fescue seedlings under LL stress resulted in increased $\mathrm{H}_{2} \mathrm{~S}$ production when compared to control plants. In addition, treatment with exogenous $\mathrm{H}_{2} \mathrm{~S}$ led to a significant increase in endogenous $\mathrm{H}_{2} \mathrm{~S}$ content when compared to $\mathrm{LL}$ treatment alone. However, HT or AOA treatment severely reduced the production of endogenous $\mathrm{H}_{2} \mathrm{~S}$ in tall fescue leaves (Fig. 5).

\section{Discussion}

The intensity and quantity of light have a strong influence on growth and development of tall fescue seedlings. Severe LL conditions can suppress the turfgrass capability to perform efficiently photosynthesis, triggering a harmful effect on various physiological and biochemical processes of plants that can exhibit diminishing survival rates (Zhang et al. 2018). $\mathrm{H}_{2} \mathrm{~S}$, as the third gasotransmitter, may play an important role in physiological and metabolic processes in plants (Guo et al. 2016). In the present study, $\mathrm{H}_{2} \mathrm{~S}$ concentration significantly increased under LL treatment compared to the control, which indicated that $\mathrm{H}_{2} \mathrm{~S}$ is possibly involved in LL responses in tall fescue. Previous studies have demonstrated that exogenous $\mathrm{H}_{2} \mathrm{~S}$ showed considerable impacts on plant leaf photosynthesis to multiple abiotic stresses (Duan et al. 2015). In our study, higher concentrations of soluble sugar and soluble protein in tall fescue after the application of NaHS might indicate that photosynthesis was elevated. We proposed that $\mathrm{H}_{2} \mathrm{~S}$ can alleviate the damage caused by LL stress through improving $P_{\mathrm{N}}$ exposure in tall fescue.

Photosynthetic efficiency could be influenced by many factors, such as stomatal or nonstomatal limitations (Hu et al. 2010). However, there are contrasting conclusions regarding stomatal movements affected by $\mathrm{H}_{2} \mathrm{~S}$. One study demonstrated that low concentration of $\mathrm{H}_{2} \mathrm{~S}$ enhances stomatal aperture, by decreasing the expression level of ABA receptor candidates (Jin et al. 2013). In contrast, another study showed that low content of $\mathrm{H}_{2} \mathrm{~S}$ represses stomatal opening through ABA-dependent signaling network (García-Mata and Lamattina 2010). In agreement with the findings of Sui et al. (2012) on responses to low light stress in Capsicum annuum, the results of the present

Fig. 4. Effects of exogenous $\mathrm{H}_{2} \mathrm{~S}$ on low light stress-induced changes in malondialdehyde (MDA) $(A)$, peroxidase (POD) $(B)$, superoxide dismutase (SOD) $(C)$, and ascorbate peroxidase (APX) $(D)$ in leaves of tall fescue seedlings over $7 \mathrm{~d}$ after treatments. CK - treatment with distilled water; LL - treatment with distilled water under LL; LL + NaHS - treatment with $500 \mu \mathrm{M}$ NaHS under LL; LL + HT - treatment with $300 \mu \mathrm{M}$ hypotaurine under LL; LL+AOA-treatment with $300 \mu \mathrm{M}$ aminooxy acetic acid under LL. Each histogram denotes a mean value of three replicates and vertical bars represent SD $(n=3)$. Means marked with different letters above the bars indicate statistically significant differences according to Duncan's multiple range tests. 


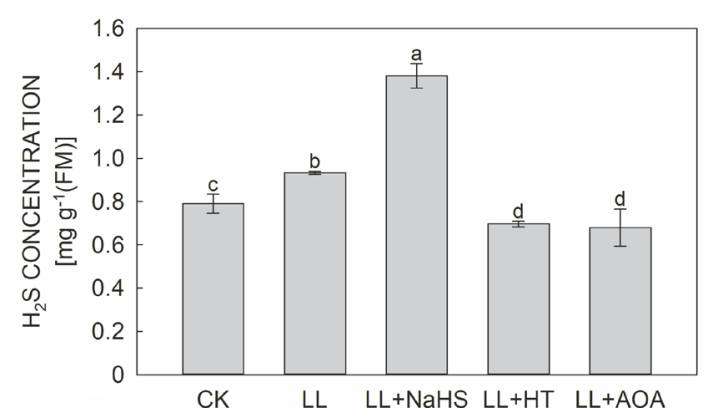

Fig. 5. Effects of exogenous $\mathrm{H}_{2} \mathrm{~S}$ on low light stress-induced changes in endogenous $\mathrm{H}_{2} \mathrm{~S}$ content in leaves of tall fescue seedlings at $7 \mathrm{~d}$ after treatments. $\mathrm{CK}$ - treatment with distilled water; LL - treatment with distilled water under LL; LL + NaHS treatment with $500 \mu \mathrm{M}$ NaHS under LL; LL + HT - treatment with $300 \mu \mathrm{M}$ hypotaurine under LL; LL + AOA - treatment with $300 \mu \mathrm{M}$ aminooxy acetic acid under LL. Each histogram denotes a mean value of three replicates and vertical bars represent SD $(n=3)$. Means marked with different letters above the bars indicate statistically significant differences according to Duncan's multiple range tests.

study demonstrated that $g_{\mathrm{s}}$ was reduced and $C_{\mathrm{i}}$ increased in tall fescue exposed to LL conditions. On the contrary, LL-treated tall fescue seedlings subjected to $\mathrm{H}_{2} \mathrm{~S}$ donor treatment effectively increased $g_{\mathrm{s}}$ and reduced $C_{\mathrm{i}}$. These results offered supporting evidence that $\mathrm{H}_{2} \mathrm{~S}$ was capable to improve the photosynthetic ability under LL stress through sustaining stomatal conductance at a high level. It has been reported that increments in $\mathrm{CO}_{2}$ assimilation and stomatal conductance were the consequence of increased Rubisco activity (Liang et al. 2005), whose level is closely linked to carboxylation efficiency and rate of carbon assimilation (Xu et al. 2013). Here, prominent increase of Rubisco activity was monitored at exogenous $\mathrm{H}_{2} \mathrm{~S}$ addition upon LL stress. We found the similar observation reported by Chen et al. (2011) in Spinacia oleracea. These results indicated $\mathrm{H} 2 \mathrm{~S}$ might modulate photosynthesis through increasing stomatal conductance and improving Rubisco activity.

Besides carboxylation, Chl fluorescence is also widely recognized as a determination of PSII function and light-harvesting efficiency. Chl fluorescence parameters, such as $\mathrm{F}_{\mathrm{v}} / \mathrm{F}_{\mathrm{m}}, \Phi_{\mathrm{PSII}}, \mathrm{q}_{\mathrm{P}}$, and ETR, were differentially attenuated in tall fescue seedlings when subjected to LL stress. In addition, HT or AOA application increased this tendency, which is similar to the findings described by Cheng et al. (2018). The decrements of $F_{v} / F_{m}$ and $\Phi_{\text {PSII }}$ suggested that LL stress generated photoinhibition by preventing the PSII electron transfer from $\mathrm{Q}_{\mathrm{A}}$ to $\mathrm{Q}_{\mathrm{B}}$ (Kumar and Prasad 2015). The apparent increments of $\mathrm{F}_{\mathrm{v}} / \mathrm{F}_{\mathrm{m}}, \Phi_{\mathrm{PSII}}, \mathrm{q}_{\mathrm{P}}$, and ETR in leaves under the combined application of NaHS and LL regime indicated that exogenous $\mathrm{H}_{2} \mathrm{~S}$ promoted photochemical reaction in PSII and photochemical conversion efficiency (Dai et al. 2016), which was consistent with enhanced Chl production. Chl was responsible for PSII function because intrinsic Chlbinding proteins could capture light energy to catalyze the water oxidation and reduction of plastoquinone (Eshaghi et al. 1999). $\mathrm{H}_{2} \mathrm{~S}$ showed effective recovery potential in enhancing electron transport efficiency and photochemical activity of PSII. In addition, changes in synthesis of photosynthetic pigment demonstrated improvement in photosynthetic efficiency (Yang et al. 2018). In this study, increased Chl content [Chl $a$, Chl $b$, and $\mathrm{Chl}(a+b)]$ in response to LL suggested the important role of exogenous $\mathrm{H}_{2} \mathrm{~S}$ in enhancing photosynthesis (Kaya et al. 2018). By contrast, the diminution of the Chl content was observed with application of HT or AOA, which was consistent with the decrease of $\mathrm{H}_{2} \mathrm{~S}$ concentration in tall fescue seedlings. These results further implied that $\mathrm{H}_{2} \mathrm{~S}$ served as a signaling molecule to regulate photosynthesis.

Environmental stresses, including LL stress, stimulated chloroplasts to generate ROS by direct transfer of excitation energy from Chl (Gill and Tuteja 2010). It can be assumed that the accumulation of cytotoxic ROS subsequently caused lipid peroxidation, overproduction of MDA, and enzyme inactivation in chloroplasts, affecting carbon assimilation of photosynthesis (Li et al. 2017). Moreover, excessive MDA might reflect that the apparatus of photosynthesis was damaged and the content of Chl was remarkably reduced (Hou et al. 2015). In the current study, LL stress increased the MDA content, implying that the functionality and integrity of membranes were severely repressed, which was similar to the finding reported in cucumber (Zhang et al. 2011). Moreover, application of HT or AOA further elevated the content of MDA in plants exposed to LL, coinciding with previous research description in wheat (Shan et al. 2017). Reinforcement of antioxidant enzyme system is regarded as an adaptive way to reduce the susceptibility to LL stress (Yang et al. 2014). It was observed that tall fescue plants supplied with NaHS under LL stress conditions demonstrated further increments in the activities of SOD, POD, and APX, which is in accordance with diminution in the content of MDA under identical treatment. The higher activities of above antioxidant enzymes might increase the resistance to oxidative damage and protected the function of photosynthetic machinery from LL-triggered damage (Dai et al. 2016). These results suggested that $\mathrm{H}_{2} \mathrm{~S}$ might act as a beneficial conductor in protecting chloroplasts and $\mathrm{Chl}$ pigment from cellular oxidative damage through increased activities of antioxidant enzyme in tall fescue.

In conclusion, LL was responsible for various morphological and physiological disruptions in tall fescue and could result in shade injury of turf aesthetic value. However, application of exogenous $\mathrm{H}_{2} \mathrm{~S}$ demonstrated improved LL tolerance of tall fescue. Our results showed that $\mathrm{H}_{2} \mathrm{~S}$, as an important signaling molecule, effectively maintained a high net photosynthetic rate through increased stomatal conductance, carboxylation efficiency, Chl content, higher activity of PSII, and alleviated ROS damage under LL stress in tall fescue seedlings. However, further studies are required to understand the underlying molecular mechanism of $\mathrm{H}_{2} \mathrm{~S}$ in regulating leaf photosynthesis.

\section{References}

Ali B., Song W.J., Hu W.Z. et al.: Hydrogen sulfide alleviates lead-induced photosynthetic and ultrastructural changes in 
oilseed rape. - Ecotox. Environ. Safe. 102: 25-33, 2014.

Beauchamp C., Fridovich I.: Superoxide dismutase: improved assays and an assay applicable to acrylamide gels. - Anal. Biochem. 44: 276-287, 1971.

Bradford M.M.: A rapid and sensitive method for the quantitation of microgram quantities of protein utilizing the principle of protein-dye binding. - Anal. Biochem. 72: 248-254, 1976.

Buege J.A., Aust S.D.: Microsomal lipid peroxidation. - Method. Enzymol. 52: 302-310, 1978.

Candan N., Tarhan L.: The correlation between antioxidant enzyme activities and lipid peroxidation levels in Mentha pulegium organs grown in $\mathrm{Ca}^{2+}, \mathrm{Mg}^{2+}, \mathrm{Cu}^{2+}, \mathrm{Zn}^{2+}$ and $\mathrm{Mn}^{2+}$ stress conditions. - Plant Sci. 165: 769-776, 2003.

Chang H., Huang H.E., Cheng C.F. et al.: Constitutive expression of a plant ferredoxin-like protein (pflp) enhances capacity of photosynthetic carbon assimilation in rice (Oryza sativa). Transgenic Res. 26: 279-289, 2017.

Chen J., Wu F.H., Wang W.H. et al.: Hydrogen sulphide enhances photosynthesis through promoting chloroplast biogenesis, photosynthetic enzyme expression, and thiol redox modification in Spinacia oleracea seedlings. - J. Exp. Bot. 62: 4481-4493, 2011.

Chen J.W., Kuang S.B., Long G.Q. et al.: Photosynthesis, light energy partitioning, and photoprotection in the shadedemanding species Panax notoginseng under high and low level of growth irradiance. - Funct. Plant Biol. 43: 479-491, 2016.

Cheng T.L., Shi J.S., Dong Y.N. et al.: Hydrogen sulfide enhances poplar tolerance to high-temperature stress by increasing $S$-nitrosoglutathione reductase (GSNOR) activity and reducing reactive oxygen/nitrogen damage. - Plant Growth Regul. 84: $11-23,2018$

Dai H.F., Xu Y.J., Zhao L.F., Shan C.J.: Alleviation of copper toxicity on chloroplast antioxidant capacity and photosystem II photochemistry of wheat by hydrogen sulfide. - Braz. J. Bot. 39: 787-793, 2016.

Duan B., Ma Y., Jiang M. et al:: Improvement of photosynthesis in rice (Oryza sativa L.) as a result of an increase in stomatal aperture and density by exogenous hydrogen sulfide treatment.Plant Growth Regul. 75: 33-44, 2015.

Emmons R.D.: Other turfgrass problems. - In: Science and Management. Pp. 386-392. Thomson Delmar, Clifton Park 2008.

Eshaghi S., Andersson B., Barber J.: Isolation of a highly active PSII-LHCII supercomplex from thylakoid membranes by a direct method. - FEBS Lett. 446: 23-26, 1999.

Fan H.H., Guan L., Li T.C. et al.: Hydrogen sulphide alleviates oxidative damage and enhances light energy transformation under high light for Dendrobium officinale. - Sci. Hortic.Amsterdam 177: 47-52, 2014.

Fu J.J., Sun Y.F., Chu X.T. et al.: Exogenous nitric oxide alleviates shade-induced oxidative stress in tall fescue (Festuca arundinacea Schreb.). - J. Hortic. Sci. Biotech. 89: 193-200, 2014.

García-Mata C., Lamattina L.: Hydrogen sulphide, a novel gasotransmitter involved in guard cell signaling. - New Phytol. 188: 977-984, 2010.

Gill S.S., Tuteja N.: Reactive oxygen species and antioxidant machinery in abiotic stress tolerance in crop plants. - Plant Physiol. Bioch. 48: 909-930, 2010.

Guo H.M., Xiao T.Y., Zhou H. et al.: Hydrogen sulfide: a versatile regulator of environmental stress in plants. - Acta Physiol. Plant. 38: 16, 2016.

Gustafsson C., Boström C.: Influence of neighboring plants on shading stress resistance and recovery of eelgrass, Zostera marina L. - PLoS ONE 8: e64064, 2013.
Hirth M., Dietzel L., Steiner S. et al.: Photosynthetic acclimation responses of maize seedlings grown under artificial laboratory light gradients mimicking natural canopy conditions. - Front. Plant Sci. 4: 334, 2013.

Hou Y.L., Meng K., Han Y. et al.: The persimmon 9-lipoxygenase gene DkLOX3 plays positive roles in both promoting senescence and enhancing tolerance to abiotic stress. - Front. Plant Sci. 6: 1073, 2015.

Hu H.L., Liu D., Li P.X., Shen W.B.: Hydrogen sulfide delays leaf yellowing of stored water spinach (Ipomoea aquatica) during dark-induced senescence by delaying chlorophyll breakdown, maintaining energy status and increasing antioxidative capacity. - Postharvest Biol. Tec. 108: 8-20, 2015.

$\mathrm{Hu}$ L., Wang Z., Huang B.: Diffusion limitations and metabolic factors associated with inhibition and recovery of photosynthesis from drought stress in a $\mathrm{C}_{3}$ perennial grass species. - Physiol. Plantarum 139: 93-106, 2010.

Huang D., Wu L., Chen J., Dong L.: Morphological plasticity, photosynthesis and chlorophyll fluorescence of Athyrium pachyphlebium at different shade levels. - Photosynthetica 49: 611-618, 2011.

Jin Z., Xue S., Luo Y. et al.: Hydrogen sulfide interacting with abscisic acid in stomatal regulation responses to drought stress in Arabidopsis. - Plant Physiol. Bioch. 62: 41-46, 2013.

Kaya C., Ashraf M., Akram N.A.: Hydrogen sulfide regulates the levels of key metabolites and antioxidant defense system to counteract oxidative stress in pepper (Capsicum annuum L.) plants exposed to high zinc regime. - Environ. Sci. Pollut. R. 25: 12612-12618, 2018.

Kumar A., Prasad M.N.V.: Lead-induced toxicity and interference in chlorophyll fluorescence in Talinum triangulare grown hydroponically. - Photosynthetica 53: 66-71, 2015.

Li Y., Fan Y., Ma Y. et al.: Effects of exogenous $\gamma$-aminobutyric acid (GABA) on photosynthesis and antioxidant system in pepper (Capsicum annuum L.) seedlings under low light stress. - J. Plant Growth Regul. 36: 436-449, 2017.

Li Z.G., Gong M., Liu P.: Hydrogen sulfide is a mediator in $\mathrm{H}_{2} \mathrm{O}_{2-}$ induced seed germination in Jatropha curcas. - Acta Physiol. Plant. 34: 2207-2213, 2012.

Li Z.G., Gong M., Xie H. et al.: Hydrogen sulfide donor sodium hydrosulfide-induced heat tolerance in tobacco (Nicotiana tabacum L.) suspension cultured cells and involvement of $\mathrm{Ca}^{2+}$ and calmodulin. - Plant Sci. 185-186: 185-189, 2012.

Liang Y.C., Zhang W.H., Chen Q., Ding R.X.: Effects of silicon on $\mathrm{H}^{+}$-ATPase and $\mathrm{H}^{+}$-PPase activity, fatty acid composition and fluidity of tonoplast vesicles from roots of salt-stressed barley (Hordeum vulgare L.). - Environ. Exp. Bot. 53: 29-37, 2005.

Lichtenthaler H.K.: Chlorophylls and carotenoids: Pigments of photosynthetic biomembranes. - Method. Enzymol. 148: 350-382, 1987.

Lilley R.M., Walker D.A.: An improved spectrophotometric assay for ribulosebisphosphate carboxylase. - BBA-Enzymology 358: 226-229, 1974.

Lu C., Qiu N., Wang, B. et al.: Salinity treatment shows no effects on photosystem II photochemistry, but increases the resistance of photosystem II to heat stress in halophyte Suaeda salsa. - J. Exp. Bot. 54: 851-860, 2003.

Mittler R., Merquiol E., Hallak-Herr E. et al.: Living under a 'dormant' canopy: a molecular acclimation mechanism of the desert plant Retama raetam. - Plant J. 25: 407-416, 2001.

Nakano Y., Asada K.: Hydrogen peroxide is scavenged by ascorbate-specific peroxidase in spinach chloroplasts. - Plant Cell Physiol. 22: 867-880, 1981.

Oliveira G., Peñuelas J.: Effects of winter cold stress on photosynthesis and photochemical efficiency of PSII of the 
mediterranean Cistus albidus L. and Quercus ilex L. - Plant Ecol. 175: 179-191, 2005.

Shan C., Zhang S., Zhou Y.: Hydrogen sulfide is involved in the regulation of ascorbate-glutathione cycle by exogenous ABA in wheat seedling leaves under osmotic stress. - Cereal Res. Commun. 45: 411-420, 2017.

Sui X.L., Mao S.L., Wang L.H. et al.: Effect of low light on the characteristics of photosynthesis and chlorophyll $a$ fluorescence during leaf development of sweet pepper. - J. Integr. Agr. 11: 1633-1643, 2012.

Upadhyaya A., Sankhla D., Davis T.D. et al.: Effect of paclobutrazol on the activities of some enzymes of activated oxygen metabolism and lipid peroxidation in senescing soybean leaves. - J. Plant Physiol. 121: 453-461, 1985.

Wang Y.Q., Li L., Cui W.T. et al.: Hydrogen sulfide enhances alfalfa (Medicago sativa) tolerance against salinity during seed germination by nitric oxide pathway. - Plant Soil 351: 107-119, 2012.

Xu C., Yin Y., Cai R. et al.: Responses of photosynthetic characteristics and antioxidative metabolism in winter wheat to post-anthesis shading. - Photosynthetica 51: 139-150, 2013.

Xu L.X., Yu J.J., Han L.B. et al.: Photosynthetic enzyme activities and gene expression associated with drought tolerance and post-drought recovery in Kentucky bluegrass. - Environ. Exp. Bot. 89: 28-35, 2013.

Xu Y.F., Fu J.J., Chu X.T. et al.: Nitric oxide mediates abscisic acid induced light-tolerance in leaves of tall fescue under high-light stress. - Sci. Hortic.-Amsterdam 162: 1-10, 2013.

Yang A.J., Anjum S.A., Wang L. et al.: Effect of foliar application of brassinolide on photosynthesis and chlorophyll fluorescence traits of Leymus chinensis under varying levels of shade. - Photosynthetica 56: 873-883, 2018.
Yang W., Fu J., Yang L. et al.: Protective effects of complementary $\mathrm{Ca}^{2+}$ on low-light-induced oxidative damage in tall fescue. Russ. J. Plant Physl+ 61: 818-827, 2014.

Zhang H., Hu L.Y., Hu K.D. et al.: Hydrogen sulfide promotes wheat seed germination and alleviates oxidative damage against copper stress. - J. Integr. Plant Biol. 50: 1518-1529, 2008.

Zhang H., Tang J., Liu X.P. et al.: Hydrogen sulfide promotes root organogenesis in Ipomoea batatas, Salix matsudana and Glycine max. - J. Integr. Plant Biol. 51: 1086-1094, 2009.

Zhang J., Shi Y., Zhang X.Z. et al.: Melatonin suppression of heat-induced leaf senescence involves changes in abscisic acid and cytokinin biosynthesis and signaling pathways in perennial ryegrass (Lolium perenne L.). - Environ. Exp. Bot. 138: 36-45, 2017.

Zhang X.H., Liu Y.H., Liu Q. et al.: Nitric oxide is involved in abscisic acid-induced photosynthesis and antioxidant system of tall fescue seedlings response to low-light stress. - Environ. Exp. Bot. 155: 226-238, 2018.

Zhang X.L., Jia X.F., Yu B. et al.: Exogenous hydrogen peroxide influences antioxidant enzyme activity and lipid peroxidation in cucumber leaves at low light. - Sci. Hortic.-Amsterdam 129: 656-662, 2011.

Zhong X.M., Shi Z.S., Li F.H., Huang H.J.: Photosynthesis and chlorophyll fluorescence of infertile and fertile stalks of paired near-isogenic lines in maize (Zea mays L.) under shade conditions. - Photosynthetica 52: 597-603, 2014.

Zhou B.Y., Guo Z.F., Xing J.P., Huang B.R.: Nitric oxide is involved in abscisic acid-induced antioxidant activities in Stylosanthes guianensis. - J. Exp. Bot. 56: 3223-3228, 2005.

(C) The authors. This is an open access article distributed under the terms of the Creative Commons BY-NC-ND Licence. 